\title{
Lymphoma of the vulva in Nigeria: Case Report
}

\author{
Wilson IB Onuigbo* \\ Department of Pathology, Medical Foundation and Clinic, Nigeria
}

Submission: December 18, 2018; Published: February 06, 2019

*Corresponding author: Wilson IB Onuigbo, Department of Pathology, Medical Foundation and Clinic, 8, Nsukka Lane, Enugu 400001, Nigeria

Abstract

Lymphoma of the vulva is acknowledged to occur rarely. Thus, only single case reports came from 9 countries worldwide. Therefore, a typical case is reported here from Nigeria, the patient hailing from the Ibo ethnic group. It is concluded that the series collected from USA provided a good platform for appreciating the epidemiology of this rare tumor including the ranges in age.

Keywords: Vulva; Lymphoma; Single cases; Collected cases, Epidemiology, Nigeria

\section{Introduction}

Vulva lymphoma is acclaimed to be rare. This is attested to by the single case reports emanating from countries as far apart as Italy [1,2], Japan [3], Korea [4], Spain [5], Switzerland [6], and Turkey [7]. Therefore, this single such report comes from Nigeria, especially as it is from the Ibo ethnic group [8].

\section{Case Report}

OB, a 47-year-old woman, attended our Institution where she first saw Dr Arthur C. Ikeme in Ward 10 with a large fungating single mass involving the right part of the mons and right labium majus. Biopsied five irregular pale pieces were submitted to the corresponding author. The largest showed hairy skin $4 \mathrm{~cm}$ across. Microscopy revealed ulcerated skin undermined by sheets of plump, round, hyperchromatic, tumor cells. They showed no differentiation. Therefore, Non-Hodgkin's lymphoma was diagnosed.

\section{Discussion}

Oddly enough, the USA contribution concerned 6 cases [9]. These patients were aged from 43 to 71 years (mean 60 years). In this range is the local case as well as those from Italy [2], Japan [3], Korea [4] and Spain [5]. Outside the range are the patients from Switzerland [6] and Turkey [7]. What of the exactitude of the sites of origins? The Italian had "a non-tender mass in the upper part of the left labium major" [2]. The Japanese was described as suffering from "vulvar swelling" [3]. The Korean was having "a mass in the right upper labium" [4]. The Spaniard exhibited "vulva lymphoma predominantly involving the clitoris" [5]. Finally, the Swiss "patient underwent biopsy of the vulvar nodule" [6].

As regards treatment, the Japanese patient failed to respond [3]; while, in a Spanish woman, the "response to chemotherapy was good and the patient remains asymptomatic after three years of follow-up." Concerning the group of 6 USA patients, who were clinically followed up, deaths occurred among 4 of them [9]. Incidentally, our local patient did not have any follow up. This was because she emerged strictly from a histopathology data pool as was advocated for easily facilitating epidemiological analysis by a Birmingham (UK) group [10]. Thus, it is important that what eventually emerged included the age patterns.

\section{References}

1. Bagella MP, Fadda G, Cherchi PL (1990) Non-Hodgkin lymphoma: A rare primary vulvar localization. Eur J Gynaecol Oncol 11(2): 153-156.

2. Clemente N, Alessandrini L, Rupolo M (2016) Primary non-Hodgkin's lymphoma of the vulva: A case report and literature review. Medicine (Baltimore) 95(10): e3041.

3. Shinohara M, Kashimura M, Kondo M (1988) A primary malignant lymphoma of the vulva-- A case report. Gan No Rinsho 34(15): 2125-2130.

4. Nam JH, Park MC, Lee KH (1992) Primary non-Hodgkin's malignant lymphoma of the vulva: A case report. J Korea Med Sci 7(3): 271-275.

5. Ferrando Marco J, Martorell MA, Carrato A, Navarro JT (1992) Primary vulvar lymphoma presenting as a clitoral tumor. Acta Obstetricia Gynecol Scand 71(7): 543-546.

6. Treglia G, Paone G, Perriard U (2014) An unusual case of diffuse large B-cell lymphoma involving the vulva evaluated by $18 \mathrm{~F}-\mathrm{FDG}$ PET/CT. Clin Nuc Med 39(10): e439-e441.

7. Tokatli F, Oz-Puyan FF, Alas R (2009) Successful treatment of primary non-Hodgkin's lymphoma of the vulva with radiation therapy. J BUON 14(1): 199-222.

8. Basden GT (1966) The Effective Power of Music in Africa. Scientific Research 5(3).

9. Vang R, Medeiros LJ, Malpica A (2000) Non-Hodgkin's lymphoma involving the vulva. Int J Gynecol Pathol 19(3): 236-242.

10. Macartney JC, Rollaston TP, Codling BW (1980) Use of a histopathology data pool for epidemiological analysis. J Clin Pathol 33(4): 351-353. 


\section{Your next submission with Juniper Publishers} will reach you the below assets

- Quality Editorial service

- Swift Peer Review

- Reprints availability

- E-prints Service

- Manuscript Podcast for convenient understanding

- Global attainment for your research

- Manuscript accessibility in different formats ( Pdf, E-pub, Full Text, Audio)

- Unceasing customer service

Track the below URL for one-step submission https://juniperpublishers.com/online-submission.php 